\title{
First record of the archaeocete whale family Protocetidae from Europe
}

\author{
Mark D. Uhen ${ }^{*}, 1$ and Hans-Jürgen Berndt ${ }^{2}$ \\ ${ }^{1}$ United States National Museum of Natural History, Department of Paleobiology, Smithsonian Institution, P.O. Box 37012, \\ Washington, DC 20013-7012, U.S.A. E-mail: uhenm@si.edu \\ 2 Dorfstraße 25, D-83115 Neubeuern, Germany. E-mail: berndt99@t-online.de
}

\begin{abstract}
Received 2 October 2007

Accepted 24 January 2008

Published 1 August 2008

\section{Key Words}

Cetacea

We describe a specimen of Eocetus sp. from the middle Eocene Stockletten Formation of Rohrdorf, Bavaria, Germany, consisting of a lumbar vertebral body and transverse processes. This specimen constitutes the first record of Eocetus, and the first confirmed record of the family Protocetidae from Europe. This new observation further supports the hypothesis that protocetids were highly aquatic and that their method of aquatic locomotion was sufficient for them to spread far from their center of origin in Indo-Pakistan.
\end{abstract}

Germany

Eocetus

Middle Eocene

\section{Introduction}

Eocetus was first described in 1904, based on a single skull placed in the species Eocetus schweinfurthi Fraas, 1904. The holotype specimen of E. schweinurthi was recovered from Gebel Mokattam near Cairo, Egypt. An additional species of Eocetus, E. wardii Uhen, 1999, was described from North Carolina, documenting the first genus of protocetid known from both sides of the North Atlantic Ocean (Uhen 1999, 2001). It was noted by Uhen (1999) that the vertebrae of Eocetus spp. were distinctly elongate, and that the texture of the bone was also very distinctive, making even small pieces of bone easy to identify as having come from individuals belonging to the genus Eocetus.

Protocetids have been described from the middle Eocene of Indo-Pakistan (Gingerich et al. 1995, 2005), North Africa (Gingerich 1992), West Africa (Andrews 1920), and the southeastern United States in North America (Albright 1996; Geisler et al. 1996; Hulbert et al. 1998; McLeod \& Barnes 1990; Uhen 1998, 1999, in press) (Fig. 1). Previously, no protocetids were known from Europe. A new specimen herein identified as Eocetus sp. is described from middle Eocene rocks of Germany. The near global distribution of protocetids during the middle Eocene demonstrates that protocetids were highly aquatic and that their method of aquatic locomotion was sufficient for them to spread far from their center of origin in Indo-Pakistan. All of the genera of Protocetidae known outside of Indo-Pakistan are members of the subfamily Georgiacetinae, so it may also be that the locomotor capabilities of this group allowed them to disperse farther compared to members of the subfamily Protocetinae, which are all restricted to Indo-Pakistan.

\section{Systematic Paleontology}

Order Cetacea Brisson, 1762

Family Protocetidae Stromer, 1908

Subfamily Georgiacetinae Gingerich et al., 2005

Genus Eocetus Fraas, 1904

\section{Eocetus sp.}

Material. Lumbar vertebral body, including left and right transverse processes (Fig. 2). The specimen is in the private collection of HansJürgen Berndt, and a cast of the specimen is housed at the United States National Museum as specimen USNM 534001.

Locality and horizon. The lumbar vertebra was discovered in May, 2003 by Hans-Jürgen Berndt in the Rohrdorf Quarry, Rohrdorf, Ba-

\footnotetext{
* Corresponding author
} 


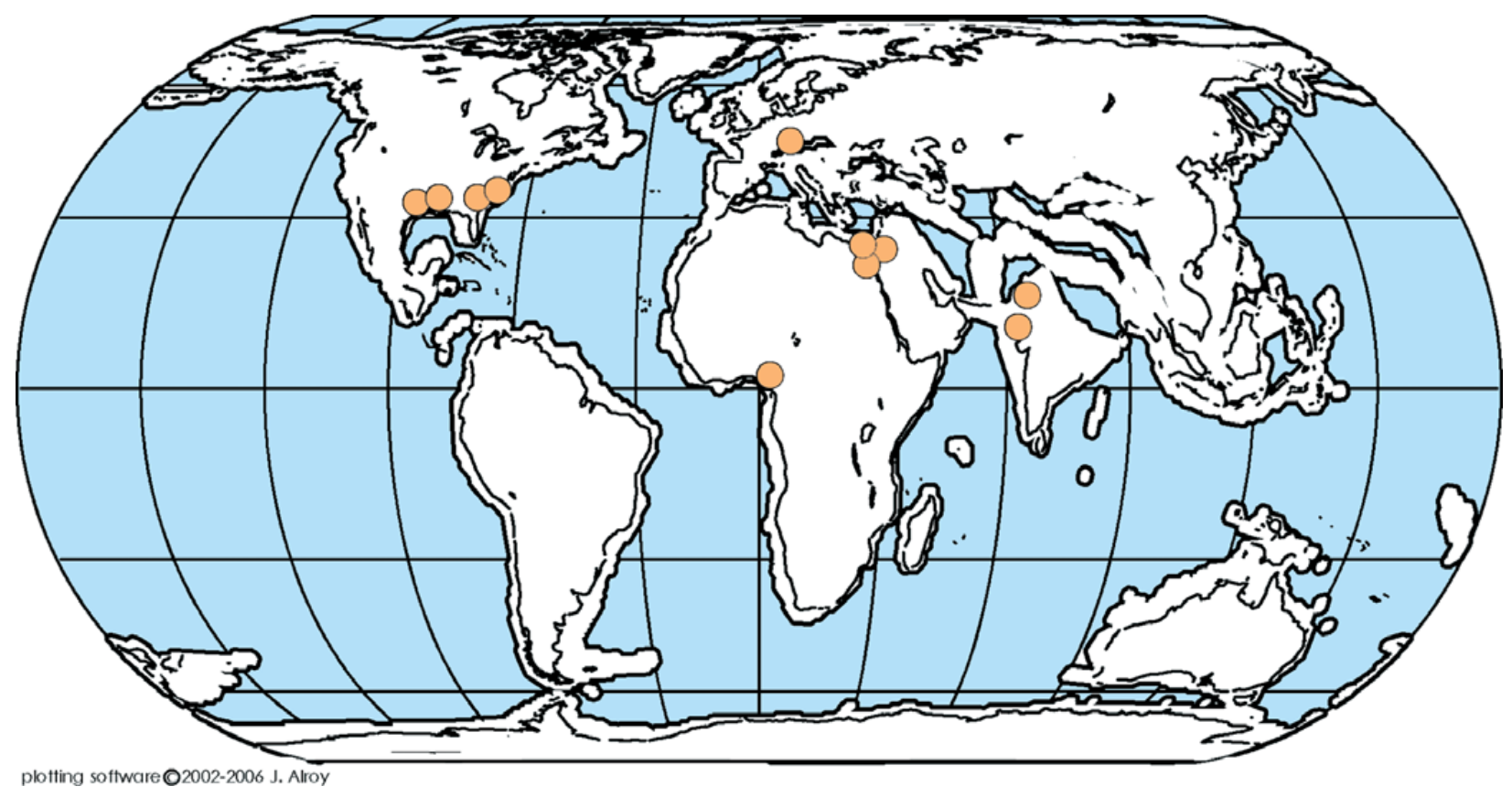

Figure 1. Reconstruction of continental plate positions at $42 \mathrm{Ma}$, during the middle Eocene. Dots represent published locations where fossils of the protocetid archaeocetes are found. Twenty-five collections are shown on the map. Data from which this map was derived is housed in the Paleobiology Database (www.pbdb.org). This figure is available in colour online at museum-fossilrecord.wiley-vch.de
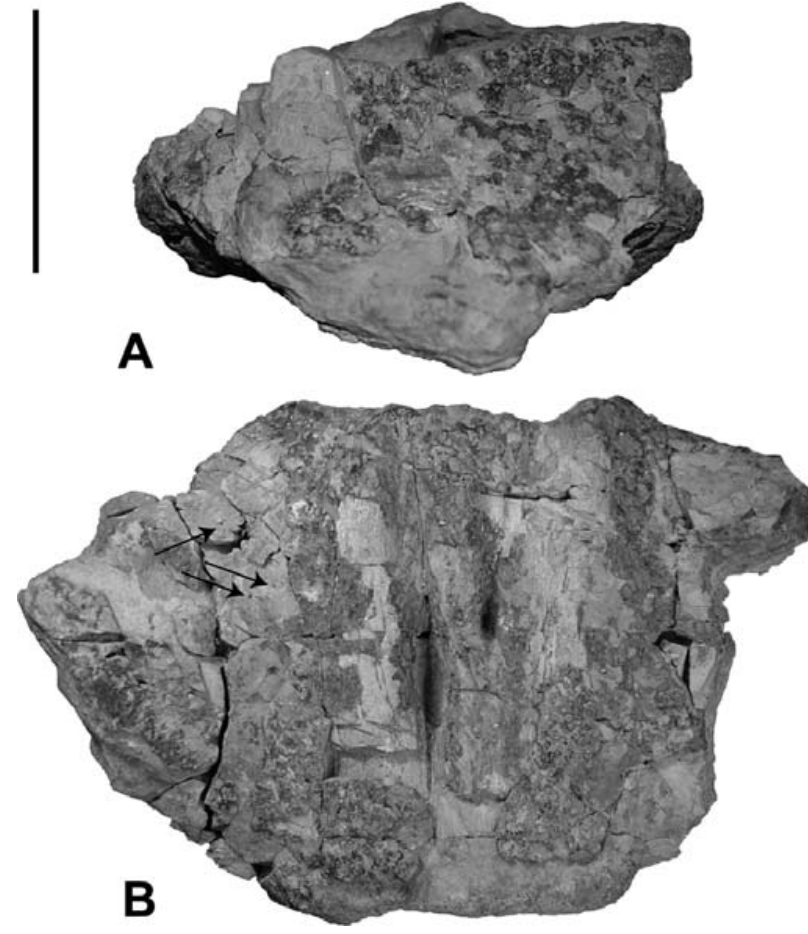

Figure 2. Eocetus sp. lumbar vertebra. A. Lateral view, B. Ventral view. Scale bar $=10 \mathrm{~cm}$. Note the antero-posterior elongation of the vertebra, the antero-posterior elongation of the transverse process, and the distinctive, pockmarked texture of the bone. The pockmarked texture is obscured by a thin layer of sediment in some areas, and a missing surface layer of bone in others. Arrows point to individual pockmarks on an undamaged area of the bone surface. varia, Germany $\left(47^{\circ} 47^{\prime} 49^{\prime \prime} \mathrm{N}, 12^{\circ} 10^{\prime} 12^{\prime \prime} \mathrm{E}\right.$, Paleobiology Database Collection 71821). The vertebra was found in a block of sandstone of the Stockletten Formation, which is Bartonian (middle Eocene) to Priabonian (late Eocene) in age (Karl 2002).

Diagnosis (after Uhen 2001). Only the diagnostic features of Eocetus vertebrae are listed here. The bone of Eocetus vertebrae has a distinctive pock-marked texture. The pock marks are actually small vascular channels that penetrate deeply into the bone. In addition, the centra, neural arches, neural spines, and transverse processes of the lumbar vertebrae are antero-posteriorly elongate, unlike the vertebrae of other protocetids. These features are all apomorphic for Eocetus. Many of the plesiomorphic features of Eocetus are found in the skull, and the hind limb, neither of which are preserved here.

Description. The specimen consists of a vertebral body, and portions of the transverse processes. The entire neural canal, and its associated spines and processes are missing. The vertebral body is elongate, compared to the width. Both anterior and posterior ends of the vertebral body are damaged. As preserved, the length of the vertebra is $210 \mathrm{~mm}$, and the width of the anterior end is approximately $161 \mathrm{~mm}$. The ratio of length/anterior width is approximately 1.3. This is the same ratio of the length/anterior width of the second lumbar vertebra of Eocetus wardii Uhen, 1999 (see Uhen 1999: tab. 1). The bases of the transverse processes are anteroposteriorly long, extending almost to the ends of the preserved portion of the vertebral body (Fig. 2).

Comparisons. The specimen from Rohrdorf compares favorably in size and morphology with specimens of 
lumbar vertebrae from North Carolina (Eocetus wardii Uhen, 1999, see Fig. 3) (Uhen 2001) and Egypt (Eocetus schweinfurthi [Fraas, 1904]). The surface of the vertebra displays the distinctive, pockmarked texture described by Uhen (1999) exclusively in Eocetus. Also, the broken surfaces of the transverse processes display the layered bone also described in Eocetus (Uhen 1999). The lumbar vertebrae of these species are very similar to each other, so it is not possible to assign this specimen to one of the two species, or to determine if it belongs to a new species of Eocetus. No other described protocetids rival Eocetus in size, nor have the distinctive pock-marked texture of the bone.

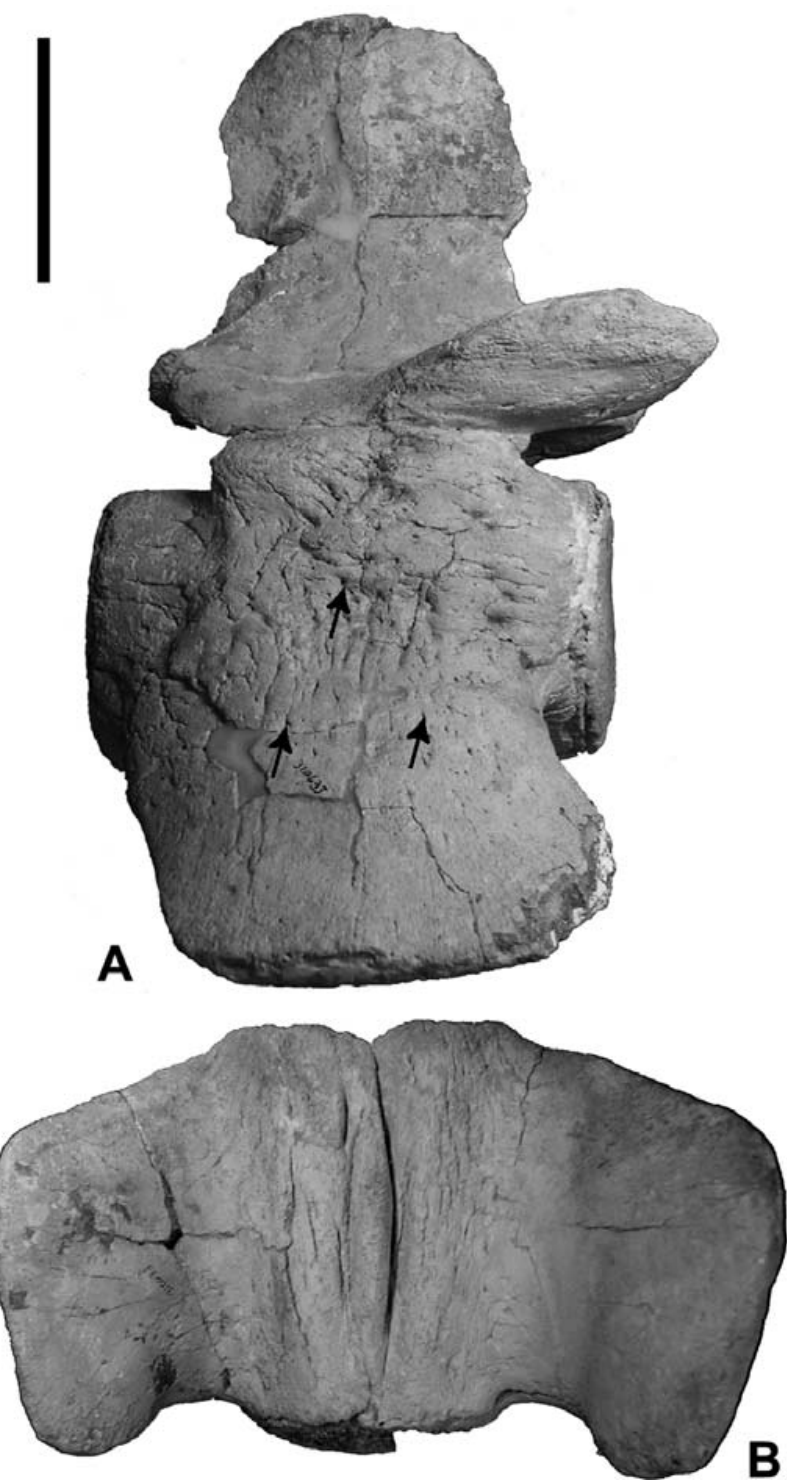

Figure 3. Eocetus wardii Uhen, 1999 lumbar vertebra. A. Lateral view, B. Ventral view. Scale $b a r=10 \mathrm{~cm}$. Compare the overall shape of the vertebral body, anteroposterior length of the transverse processes, and the distinctive pock-marked texture of the bone to the specimen in Figure 2. Arrows point to individual pockmarks on the bone surface.

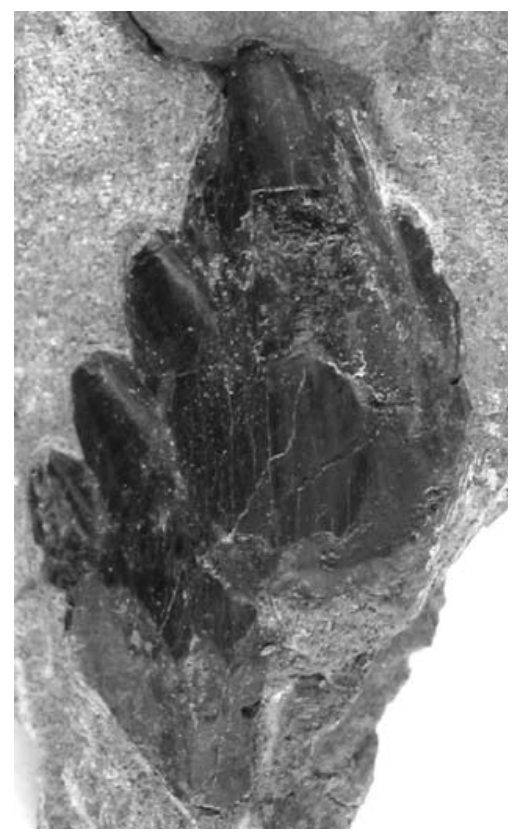

Figure 4. Basilosaurid tooth from Rohrdorf quarry. Based on the small size of the tooth, it is probably a dorudontine, but that cannot be determined without more of the skeleton. Based on the morphology of the tooth, particularly the presence of accessory denticles on both the anterior and posterior margins, it is a premolar identified as Basilosauridae indet.

\section{Discussion}

This specimen of Eocetus demonstrates that members of this protocetid ranged farther than any other protocetid of the middle Eocene, since Eocetus is now known from North Africa, Europe, and North America. While this may not be surprising, until very recently, no protocetids had formally been described from North America and none have been known from Europe until now.

In addition to the specimen of Eocetus, a premolar tooth of a basilosaurid was also recovered from the Stockletten Formation (Fig. 4). This tooth is not assignable to any particular genus or even to subfamily, but it is important to note its presence. If this tooth is truly from the same stratigraphic layer as the Eocetus sp. vertebra, and the vertebra does not represent a redeposition of an older block of sediment, then this represents the first co-occurrence of a protocetid and a basilosaurid. This tooth is very similar to those found in a similar age deposit at St. Pankraz, Austria (Uhen \& Tichy 2000).

\section{Acknowledgements}

We would like to thank three anonymous reviewers who made helpful comments on earlier drafts of this paper. Their comments and suggestions greatly improved the content of this manuscript, but any failings are entirely those of the authors. 


\section{References}

Albright, L. B., III. 1996. A protocetid cetacean from the Eocene of South Carolina. - Journal of Paleontology 70 (3): 519-522.

Andrews, C. W. 1920. A description of new species of zeuglodont and of leathery turtle from the Eocene of southern Nigeria. Proceedings of the Zoological Society of London 1919 (3-4): 309-319.

Brisson, A. D. 1762. Regnum Animale in Classes IX distributum sive synopsis methodica. Edito altero auctior. Theodorum Haak, Leiden.

Fraas, E. 1904. Neue Zeuglodonten aus dem unteren Mittelecocän vom Mokattam bei Cairo. - Geologische und Palæontologische Abhandlungen, Jena, Neue Folge 6 (3): 199-220.

Geisler, J. H., Sanders, A. E. \& Luo, Z. 1996. A new protocetid cetacean from the Eocene of South Carolina, U.S.A; phylogenetic and biogeographic implications. - The Paleontological Society Special Publication 8 (Sixth North American Paleontological Convention Abstracts of Papers): 139.

Gingerich, P. D. 1992. Marine mammals (Cetacea and Sirenia) from the Eocene of Gebel Mokattam and Fayum, Egypt: stratigraphy, age and paleoenvironments. - The University of Michigan Museum of Paleontology Papers on Paleontology 30: 1-84.

Gingerich, P. D., Arif, M. \& Clyde, W. C. 1995. New archaeocetes (Mammalia, Cetacea) from the middle Eocene Domanda Formation of the Sulaiman Range, Punjab (Pakistan). - Contributions from the Museum of Paleontology, The University of Michigan 29 (11): 291-330.

Gingerich, P. D., Zalmout, I. S., Ul-Haq, M. \& Bhatti, M. A. 2005. Makracetus bidens, a new protocetid archaeocete (Mammalia, Ce- tacea) from the early middle Eocene of Balochistan (Pakistan). Contribution from the Museum of Paleontology, The University of Michigan 31 (9): 197-210.

Hulbert, R. C., Petkewich, R. M. Jr., Bishop, G. A., Bukry, D. \& Aleshire, D. P. 1998. A new middle Eocene protocetid whale (Mammalia: Cetacea: Archaeoceti) and associated biota from Georgia. - Journal of Paleontology 72 (5): 907-927.

Karl, H.-V. 2002. Über Reptilienreste aus dem Alttertiär des nördlichen Alpenvorlandes bei Siegsdorf/Oberbayern. - Joannea Geologie und Paläontologie 4: 69-81.

McLeod, S. A. \& Barnes, L. G. 1990. Archaeocete cetaceans from the Atlantic Coastal Plain of the United States, including a new protocetid. - Journal of Vertebrate Paleontology 9 (3): 35A.

Stromer, E. 1908. Die Urwale (Archaeoceti). - Anatomischer Anzeiger 33 (4-5): 81-88.

Uhen, M. D. 1998. New protocetid (Mammalia, Cetacea) from the late middle Eocene Cook Mountain Formation of Louisiana. - Journal of Vertebrate Paleontology 18 (3): 664-668.

Uhen, M. D. 1999. New species of protocetid archaeocete whale, Eocetus wardii (Mammalia, Cetacea), from the middle Eocene of North Carolina. - Journal of Paleontology 73 (3): 512-528.

Uhen, M. D. 2001. New material of Eocetus wardii (Mammalia, Cetacea), from the middle Eocene of North Carolina. - Southeastern Geology 40 (2): 135-148.

Uhen, M. D. in press. New protocetid whales from Alabama and Mississippi, and a new cetacean clade, Pelagiceti. - Journal of Vertebrate Paleontology.

Uhen, M. D. \& Tichy, G. 2000. A new basilosaurid archaeocete from Austria. - Journal of Vertebrate Paleontology 20 (3): 74A-75A. 